\title{
Article \\ Physiological and Genomic Characterization of Two Novel Bacteroidota Strains Asinibacterium spp. OR43 and OR53
}

\author{
Ryann M. Brzoska ${ }^{1}$, Richard E. Edelmann ${ }^{2}$ and Annette Bollmann ${ }^{1, *}$ \\ 1 Department of Microbiology, Miami University, 700 East High Street, 212 Pearson Hall, \\ Oxford, OH 45056, USA; brzoskrm@miamioh.edu \\ 2 Center for Advanced Microscopy and Imaging, Miami University, 100 Bishop Circle, Upham Hall, \\ Oxford, OH 45056, USA; edelmare@miamioh.edu \\ * Correspondence: bollmaa@miamioh.edu
}

check for updates

Citation: Brzoska, R.M.; Edelmann, R.E.; Bollmann, A. Physiological and Genomic Characterization of Two Novel Bacteroidota Strains Asinibacterium spp. OR43 and OR53. Bacteria 2022, 1, 33-47. https:// doi.org/10.3390/bacteria1010004

Academic Editor: Bart C. Weimer

Received: 22 December 2021

Accepted: 2 February 2022

Published: 8 February 2022

Publisher's Note: MDPI stays neutral with regard to jurisdictional claims in published maps and institutional affiliations.

Copyright: () 2022 by the authors. Licensee MDPI, Basel, Switzerland. This article is an open access article distributed under the terms and conditions of the Creative Commons Attribution (CC BY) license (https:// creativecommons.org/licenses/by/ $4.0 /)$.

\begin{abstract}
Asinibacterium spp. (Family Chitinophagaceae, Phylum Bacteroidota) are abundant in environments contaminated with heavy metals. We characterized the physiology and genome of two Asinibacterium species to elucidate their ability to survive and grow at ambient conditions in the uranium-contaminated environments. Both strains were able to grow at $\mathrm{pH} 4.5$ or $50 \mathrm{mM}$ nitrate under aerobic conditions and did not grow with alternative electron acceptors under anaerobic conditions. Asinibacterium sp. OR53 grew in medium with uranium concentrations up to $300 \mu \mathrm{M}$ uranium while Asinibacterium sp. OR43 could not grow at uranium concentrations $>200 \mu \mathrm{M}$. Elemental mapping using energy dispersive $\mathrm{X}$-ray spectroscopy indicate that uranium co-localized with phosphoruscontaining compounds on the cell surface. Genes potentially encoding resistance mechanisms to a variety of heavy metals were detected in the genomes of both strains. The localization of uranium and missing acidic and alkaline phosphatase genes in the genome suggest that biosorption of uranium to the lipopolysaccharide layer might be the mechanism of uranium resistance. In summary, Asinibacterium spp. OR43 and OR53 are physiologically similar to closely related strains within the Chitinophagaceae family but are uniquely acclimated to the presence of uranium and other heavy metals prevalent in the subsurface at Oak Ridge, Tennessee.
\end{abstract}

Keywords: uranium resistance; Asinibacterium; genome

\section{Introduction}

The family Chitinophagaceae in the phylum Bacteroidota contains among many other genera, the genera Sediminibacterium, Hydrotalea, and Asinibacterium [1-4]. Described strains belonging to these genera have been found in freshwater (Sediminibacterium and Hydrotalea), sediments (Sediminibacterium and Hydrotalea), soil (Sediminibacterium), and Donkey milk powder (Asinibacterium) [1-6]. Sediminibacterium spp. and Hydrotalea spp. are the closest relatives to Asinibacterium lactis [2]. Sequences closely related to Sediminibacterium spp. were detected in freshwater biofilms, eutrophic lakes, salt water, wastewater, and the gut of beetles and cows [7-15]. In addition, many sequences related to Sediminibacterium spp. were found in contaminated environments with high concentrations of organic compounds and/or heavy metals [16-20].

Asinibacterium spp. OR43 and OR53 (formerly called Sediminibacterium spp. OR43 and OR53) from the family Chitinophagaceae were isolated from the highly contaminated subsurface sediment at the Integrated Field Research Challenge (IFRC) in Oak Ridge, TN, USA [21]. The prevalence of members of the genera Sediminibacterium and Asinibacterium in contaminated environments suggests these microbes could have physiological and genomic characteristics that enable them to function in the presence of contaminants such as heavy metals. The ground water at the sampling site is contaminated with heavy metals such as cadmium, chromium, cobalt, nickel, and uranium, has a low $\mathrm{pH}$ ( $\mathrm{pH}$ 3-3.5), and a high nitrate concentration (http://www.esd.ornl.gov/ orifrc, accessed on 20 December 2021). 
Many heavy metals are essential for metabolism in low concentrations, but can have damaging effects on the physiology of microbes in high concentrations. Effects include disrupting metabolic pathways by inhibiting protein enzymatic activity, displacing native metals from their binding sites, and oxidative stress caused by hydrogen peroxide $\left(\mathrm{H}_{2} \mathrm{O}_{2}\right)$ production [22,23]. Microbes have developed mechanisms to decrease intracellular heavy metal concentrations and thereby avoid the damaging effects of heavy metals. The most common mechanisms to reduce the concentration of heavy metals are active transporters and efflux pumps [22-24]. Uranium is a heavy metal without a known biological function for the cell [25]. Thus far, no efflux pumps or transporters for the detoxification of uranium have been discovered. Therefore, microorganisms are likely to use alternative tolerance/detoxification mechanisms such as uranium as an electron acceptor (bioreduction), passive sorption to anionic groups in the cell wall (biosorption), and accumulation inside of the cell (bioaccumulation) or active precipitation outside of the cell (biomineralization) [25].

Here we present a study of the physiological and genomic attributes of Asinibacterium spp. OR43 and OR53, two strains isolated from the uranium-contaminated subsurface sediment at Oak Ridge, Tennessee [21]. The growth of both strains was tested under a variety of environmentally relevant conditions such as $\mathrm{pH}$, nitrate, and uranium. The closed genome of Asinibacterium sp. OR53 and the draft genome of Asinibacterium sp. OR43 were analyzed and compared with an emphasis on the genes potentially related to the resistance of uranium and other heavy metals.

\section{Results and Discussion}

Phylogenetically Asinibacterium spp. OR43 and OR53 were most closely related to Asinibacterium lactis a strain isolated from Donkey milk [2] (Figure 1). Other close relatives include Vibrionimonas magnilacihabitans and Hydrotalea spp. isolated from freshwater and Sediminibacterium spp. isolated from soils and sediments [1,3-5,26]. Additionally, 16S rRNA gene sequences closely related to Sediminibacterium spp. were detected in contaminated soil and sediment environments [7-15,17-21,27-30]. In summary, most $16 \mathrm{~S}$ rRNA sequences and closely related isolates to Asinibacterium spp. OR43 and OR53 were found in soils and sediments indicating that soils and sediments are their primary habitat.

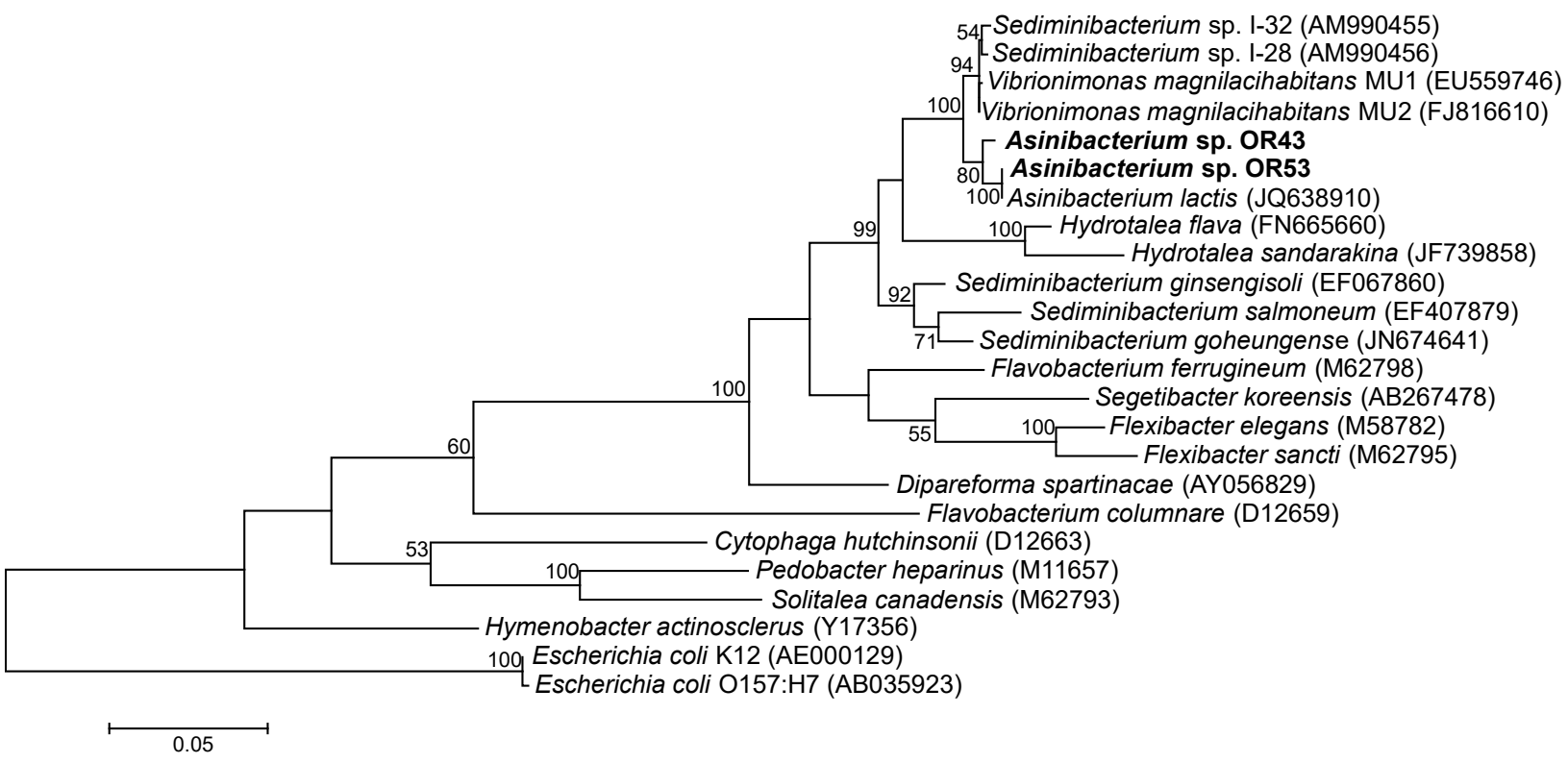

Figure 1. Maximum likelihood phylogenetic tree based on 16S rRNA gene sequences showing the phylogenetic position of Asinibacterium sp OR43 and OR53. Numbers at the nodes represent bootstrap values $>50 \%$ after 100 replications. 


\subsection{Physiological Characterization}

Physiologically, Asinibacterium spp. OR43 and OR53 were very similar to each other and to related cultured strains (Tables S1 and S2). Both strains were aerobic, did not use alternative electron acceptors under anaerobic conditions, had a low salt tolerance, and grew optimally at pH 5.5 to 7 and at temperatures between 27 and $30{ }^{\circ} \mathrm{C}$ (Table S1). Both strains utilized many different sugars as carbon sources (Table $\mathrm{S} 1$ ). iso- $\mathrm{C}_{15: 0}$, iso- $\mathrm{C}_{15: 1} \mathrm{G}$, and iso- $\mathrm{C}_{17: 0} 3-\mathrm{OH}$ were the dominant fatty acids in both strains (Table S2). The physiological characterization shows that Asinibacterium spp. OR43 and OR53 behave very similarly to their closest cultured relatives (Tables S1 and S2) [1,3-5,26].

\subsection{Growth in the Presence of Stress Factors}

Asinibacterium spp. OR43 and OR53 were isolated from the IFRC area in Oak Ridge, $\mathrm{TN}$ [21]. The nitrate concentration in the ground water around the borehole near where Asinibacterium spp. OR43 and OR53 were isolated was 1541-1575 mg/L (24.9-25.4 mM), with a uranium concentration and $\mathrm{pH}$ between 15.97 and $17.03 \mathrm{mg} / \mathrm{L}(67.1$ and $71.5 \mu \mathrm{M})$ and 2.99 and 3.52, respectively (http: / / www.esd.ornl.gov/ orifrc, accessed on 20 December 2021). Growth experiments were conducted to evaluate the growth of the isolates under conditions similar to the original environment. Under aerobic conditions both strains grew with the highest growth rate at $\mathrm{pH}$ 5-7 (Figure 2A). The growth rates decreased at $\mathrm{pH} 4.5$ and $\mathrm{pH} 8$ and no growth was observed at $\mathrm{pH}$ lower than 4.5 . In the presence of uranium, the growth rates decreased with increasing uranium concentrations (Figure 2B). Asinibacterium sp. OR43 grew in the presence of up to $200 \mu \mathrm{M}$ uranium, and Asinibacterium sp. OR53 grew in the presence of up to $300 \mu \mathrm{M}$ uranium (Figure 2B). Both strains grew in the presence of up to $50 \mathrm{mM}$ nitrate (Figure $2 \mathrm{C}$ ). These results indicate that Asinibacterium spp. OR43 and OR53 are able to withstand uranium and nitrate concentrations comparable to the concentrations in their original environment but are inhibited by environmentally relevant $\mathrm{pH}$ values.
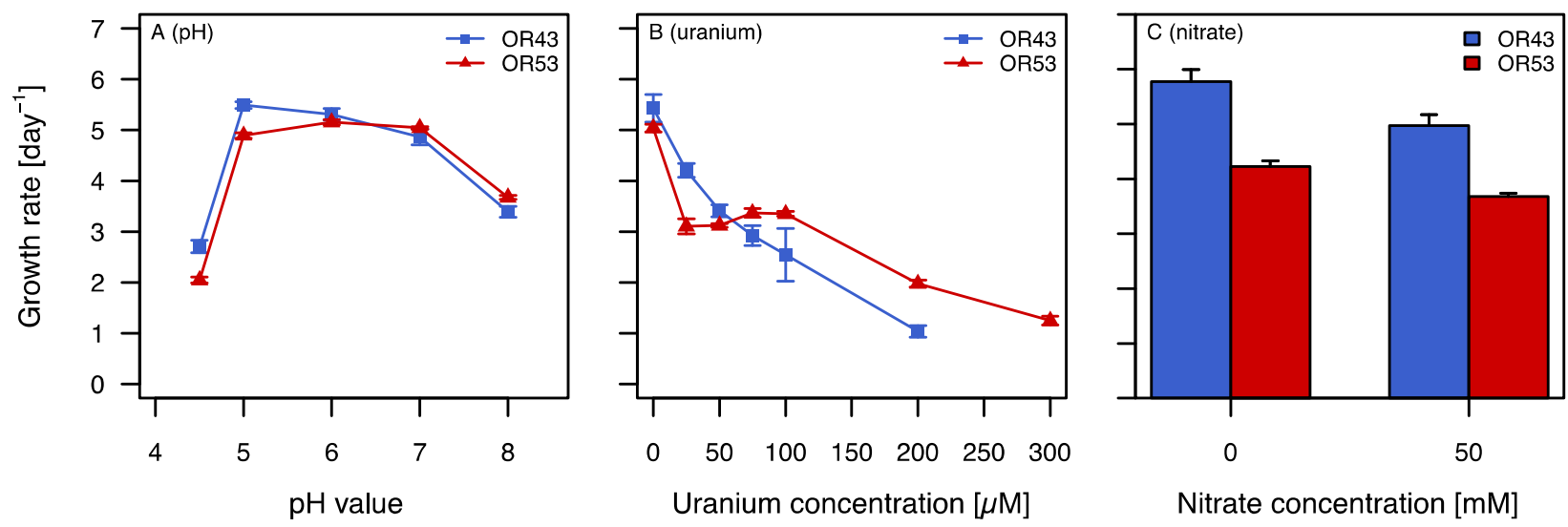

Figure 2. Growth rate $\left(\right.$ day $\left.^{-1}\right)$ of Asinibacterium spp. OR43 and OR53 in the presence of different $\mathrm{pH}$ values (A); uranium (B); and nitrate (C) concentrations (mean $\pm \mathrm{SD} ; \mathrm{n}=3-6$ ). No growth was observed at $\mathrm{pH}<4.5$, at uranium concentrations $>200 \mu \mathrm{M}(\mathrm{OR} 43)$ and $>300 \mu \mathrm{M}(\mathrm{OR} 53)$, and at nitrate concentrations $>50 \mathrm{mM}$.

\subsection{Growth of Asinibacterium sp. OR53 in the Presence of Uranium}

Additional experiments were conducted to characterize the response of Asinibacterium sp. OR53 to elevated levels of uranium. Asinibacterium sp. OR53 was used due to its ability to grow at higher uranium concentrations than Asinibacterium sp. OR43 (Figure 2B). In addition, the strain was also an abundant member of an artificial consortium incubated in the presence of $200 \mu \mathrm{M}$ uranium for 300 generations [31]. During growth experiments, a trend was discovered between the measured uranium concentration in the medium and the growth of Asinibacterium sp. OR53 over time (Figure 3). In the absence of uranium, 
growth of Asinibacterium sp. OR53 started within a few hours after inoculation (Figure 3). In the presence of $300 \mu \mathrm{M}$ uranium the culture had a lag phase of around 3 days before exponential growth started. The uranium (VI) concentration in the medium decreased from $220 \mu \mathrm{M}$ to around $70 \mu \mathrm{M}$ within four days and stayed at that level until the end of the experiment (day 7). The uranium concentration decreased also in medium controls without Asinibacterium sp. OR53, but the decrease was much slower, showing that the presence of Asinibacterium sp. OR53 accelerated the decrease in uranium (Figure S1). The results showed that the uranium concentration must decrease to around $90 \mu \mathrm{M}$ before Asinibacterium sp. OR53 can grow (Figure 3).

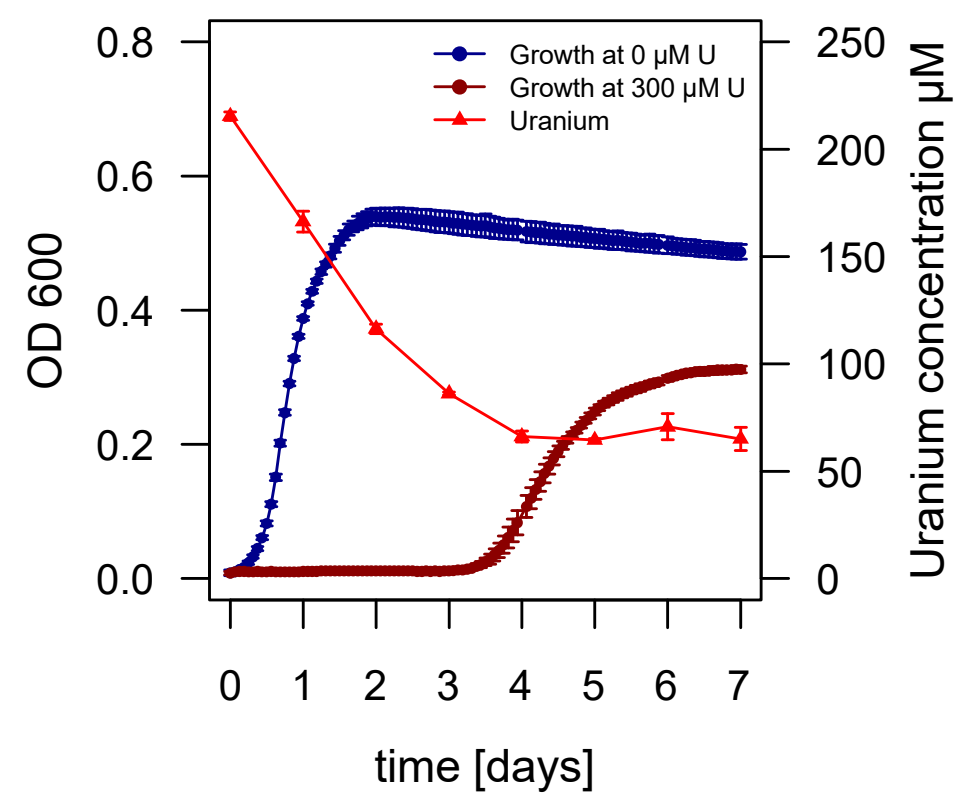

Figure 3. $\mathrm{OD}_{600}$ of Asinibacterium sp. OR53 grown in the absence $(0 \mu \mathrm{M})$ and presence $(300 \mu \mathrm{M})$ of uranium and the measured uranium concentration in the medium over time (mean $\pm S D ; n=3$ ).

TEM analysis of unstained, whole mounted Asinibacterium sp. OR53 cells showed a higher signal contrast (Z-contrast) when grown in the presence of uranium (Figure 4B) than in the absence of uranium (Figure 4A) indicating an association of uranium with the cells. STEM and EDS were used on uranium-exposed cells to visualize uranium localization through elemental mapping. Bright-field STEM imaging revealed lighter, low signal contrast cells surrounding one distinctly higher signal contrasted cell (Figure 5A). EDS analysis showed that the distribution of uranium (Figure 5C) matched closely with the dark plaques present on the higher signal contrasted cell (Figure 5A). In addition, phosphorus localized with all cells, while uranium was only detected in the darkly contrasted cell (Figure 5A-C). Overlays of phosphorus and uranium resulted in bright co-localization of the two elements along cell peripheries (Figure 5D) suggesting that both elements were distributed across the cell surface. The distribution of the two elements across the cell and the bright co-localization of both elements at the periphery of Asinibacterium sp. OR53 cells suggest that this strain could use biomineralization or biosorption as a mechanism of uranium resistance. Biomineralization is an active mechanism that uses phosphate from phosphatases to precipitate uranium [25]. In contrast, biosorption is a passive mechanism where uranium binds to extracellular structures such as the LPS layer. In the LPS layer, uranium can be bound by different ligands in the cellwall such as carboxyl, amine, hydroxyl, and phosphoryl groups [25]. In Pseudomonas aeruginosa most of uranium is bound to phosphoryl groups while small amounts are bound to carboxyl groups in the LPS layer [32]. 

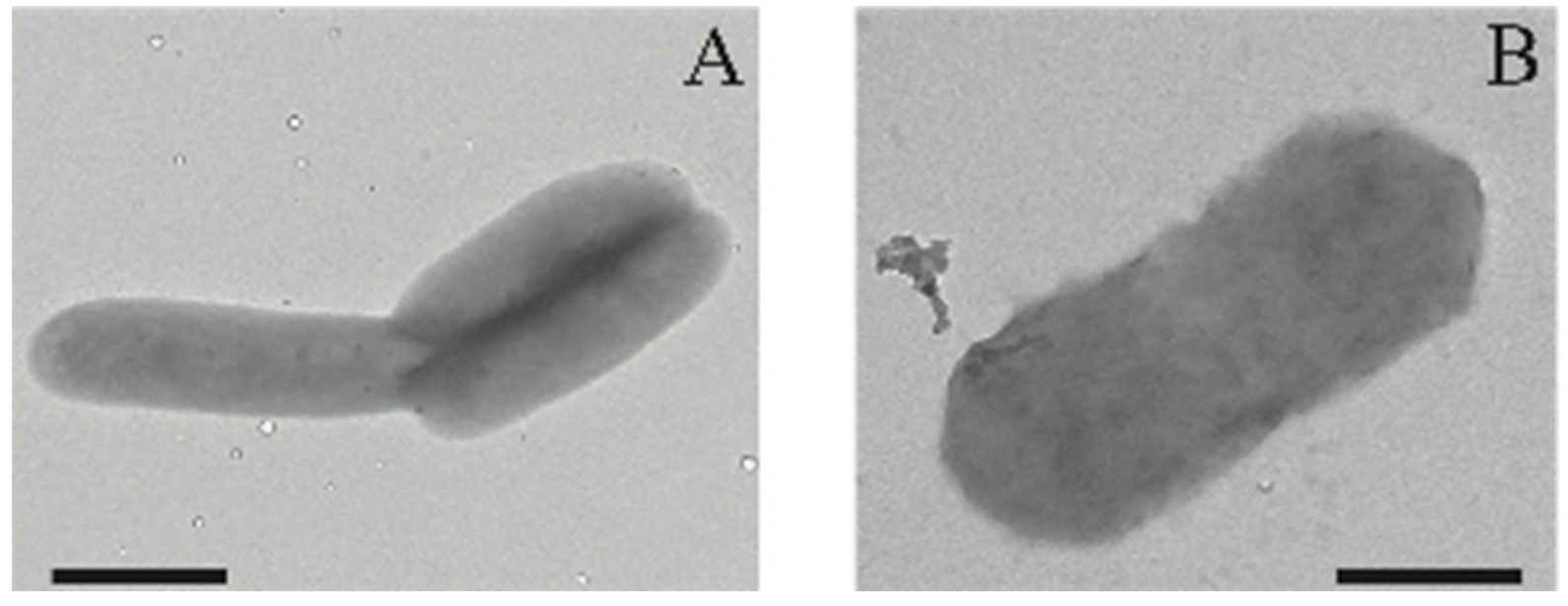

Figure 4. TEM micrographs of unstained, whole-mount cells of Asinibacterium sp. OR53 grown in the absence (A) and presence (B) of $300 \mu \mathrm{M}$ uranium. Scale bars $=1.0 \mu \mathrm{m}$.

Interestingly, TEM micrographs and EDS analysis indicate that some cells did not have detectable levels of uranium (Figure 5). It is possible that Asinibacterium sp. OR53 cells that bind uranium above a certain level are no longer metabolically active or are severely debilitated. Healthy cells or cells with very low concentrations of bound uranium may initiate growth when the uranium concentration decreases below a certain threshold (Figure 3). Below the threshold Asinibacterium sp. OR53 may have additional mechanisms to withstand the toxic effects of uranium so that the cells do not need to bind uranium anymore. However, the cells still grow slower and produce less biomass in the presence of uranium than in the absence (Figure 3), indicating that withstanding the toxic effects of uranium negatively impacts their growth.

\subsection{Genomes of Asinibacterium spp. OR43 and OR53}

The genomes of Asinibacterium spp. OR43 and OR53 [33] were analyzed with the focus on genes involved in processes important at the IFRC: nitrate metabolism, $\mathrm{pH}$ homeostasis, and heavy metal resistance genes. General information about the genomes can be found in Tables S3-S5. The average nucleotide identity (ANI) calculated by the IMG database resulted in an identity between the two genomes of $96.4 \%$ indicating that the genomes belonged to the same species [34,35].

Genes involved in the nitrate metabolism: Denitrification is the reduction of nitrate to molecular nitrogen via the intermediates nitrite, nitric oxide, and nitrous oxide [36]. During dissimilatory nitrate reduction to ammonium (DNRA) nitrate is reduced to nitrite and then to ammonium [36]. Both processes are important processes in the global nitrogen cycle. Asinibacterium spp. OR43 and OR53 were missing the nitrate reductase (napAB) necessary to use nitrate as a terminal electron acceptor during denitrification and/or the DNRA pathway (Tables 1 and S6). Nitrite is reduced by the copper-containing nitrite reductase (nirK) [36], which was detected in both genomes. Both strains encoded the genes for the nitric oxide reductase (qNOR). qNOR in contrast to other nitric oxide reductases is not part of an operon and has been shown to be functional in pathogens and other microorganisms in the absence of the other enzymes of the denitrification pathway [37,38]. The final step of denitrification is catalyzed by the nitrous oxide reductase, a multi subunit enzyme. The nitrous oxide reductase (nosZ) is encoded in both genomes together with the nosLDFY cluster that encodes the copper sulfide center ( $\mathrm{CuZ}$ center) and is important in electron transfer (Table S6) [39]. The detected nos genes are often found together with the $n o s R$ gene, a gene involved in the regulation of the nitrous oxide reductase activity [39], which was not detected in the Asinibacterium spp. genomes. Based on the genes present neither strain can use nitrate. The absence of potential genes for nitrate reduction was 
supported by the inability of both strains to grow under anaerobic conditions with nitrate as a terminal electron acceptor (Table S1). Asinibacterium spp. OR43 and OR53 were isolated from an environment with a relatively low nitrate concentration and both strains were capable of withstanding environmental nitrate concentrations under laboratory conditions (Figure 2C) [21]. However, strains closely related to Asinibacterium spp. OR43 and OR53 were detected with molecular methods in areas with nitrate concentrations higher than $700 \mathrm{mM}$ [16]. These strains might have a higher tolerance than Asinibacterium spp. OR43 and OR53 to nitrate or live in association with nitrate-reducers that keep nitrate concentrations low for surrounding microorganisms.
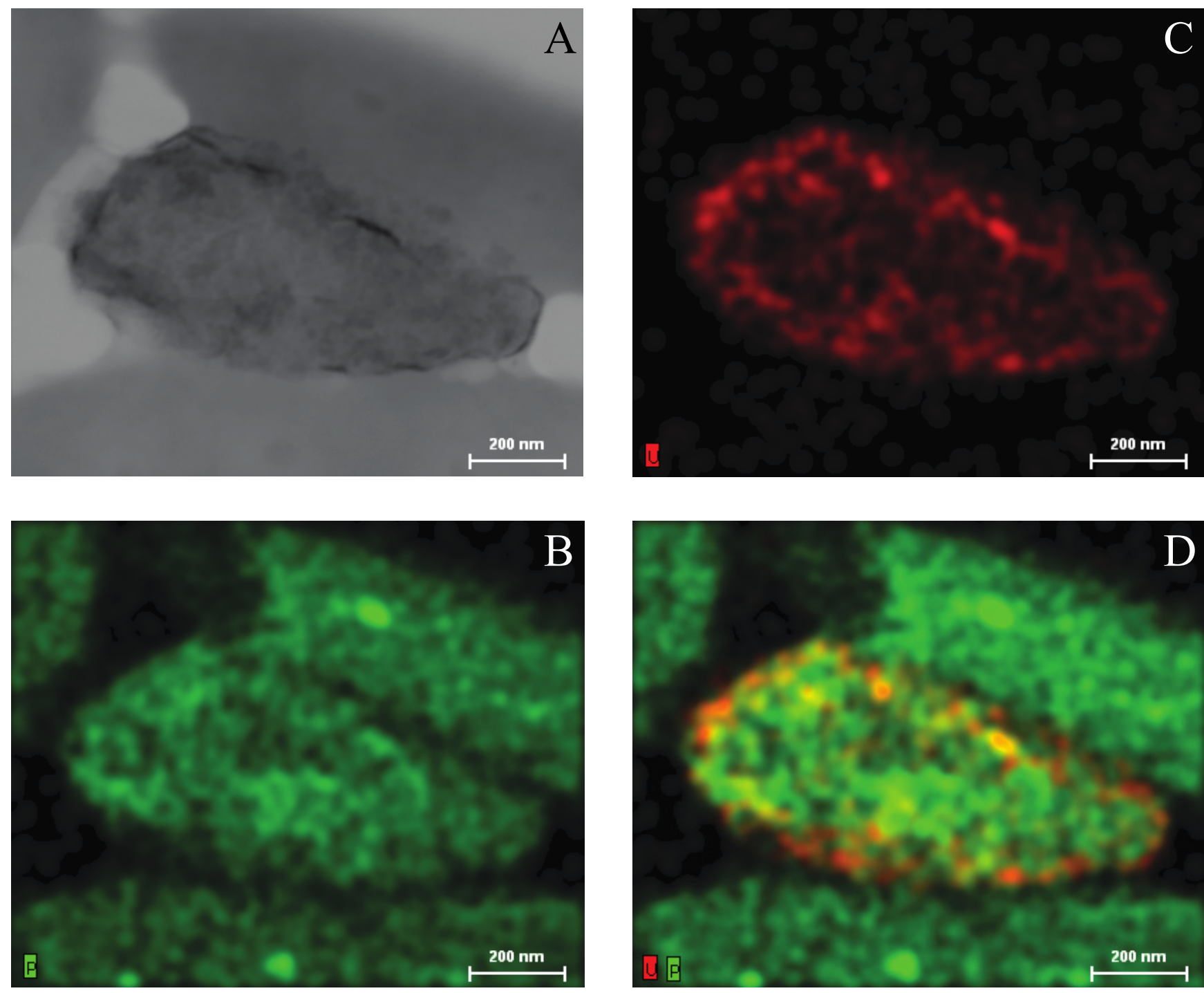

Figure 5. Elemental analysis of whole-mounted cells of Asinibacterium sp. OR53 grown in the presence of $300 \mu \mathrm{M}$ uranium. Bright-field STEM micrograph of Asinibacterium sp. OR53 cells (A); an EDS mapping of the distribution of elemental phosphorus (green) (B); the distribution of elemental uranium (red) (C); and the distribution of elemental phosphorus and uranium (D). Scale bars $=0.2 \mu \mathrm{m}$. 
Table 1. Presence (+) and absence (-) of genes involved in nitrate metabolism in Asinibacterium spp. OR43 and OR53 genomes.

\begin{tabular}{lccc}
\hline Gene Product Name & Gene Symbol & OR43 & OR53 \\
\hline $\begin{array}{l}\text { Nitrate/nitrite transporter } \\
\text { Nitrite/nitrate transporter }\end{array}$ & narK & + & + \\
ABC transporter & $\operatorname{nrtABC}$ & + & - \\
\hline Assimilatory nitrate reduction & & & + \\
Ferredoxin nitrate reductase & $\operatorname{narB}$ & & + \\
\hline Dissimilatory nitrate reduction & & + & \\
Nitrite reductase & $\operatorname{nirBD}$ & & - \\
\hline Denitrification & & - & + \\
Nitrate reductase & $\operatorname{napAB}$ & + & + \\
Nitrite reductase (copper containing) & $\operatorname{nirK}$ & + & + \\
Nitric oxide reductase (qNOR) & $\operatorname{norC}$ & + & \\
Nitrous oxide reductase & $\operatorname{nosZLDFY}$ & & + \\
\hline
\end{tabular}

Genes potentially involved in $\mathrm{pH}$ homeostasis at low $\mathrm{pH}$ : F-type ATPases (Atp) are capable of proton export and were shown to be important for Listeria monocytogenes to persist in acidic environments $[40,41]$. F-type ATPases often work concurrently with potassium transporters (Kup) to balance membrane potential during proton extrusion [42-44]. Asinibacterium spp. OR43 and OR53 had all genes necessary for a functional F-type ATPase (atpABEFH, atpC, atpD, and $\operatorname{atp} G$ ) in addition to one copy of the high affinity potassium transporter $(k d p A B C)$ and two copies of the low affinity potassium transporter (kup) (Tables 2 and S7). Both strains were able to grow at $\mathrm{pH}$ values as low as 4.5 (Figure 2A). The ability to tolerate $\mathrm{pH} 4.5$ is very likely due to the presence of the F-type ATPase (Atp) and the low affinity potassium transporter (Kup). Bacteria that are able to withstand $\mathrm{pH}<3$ typically have genes that encode acid resistance such as lysine-, glutamine-, or argininedecarboxylases [45], which are not present in the genomes of Asinibacterium spp. OR43 and OR53. These results indicate that Asinibacterium spp. OR43 and OR53 are neutrophilic bacteria, which is consistent with previously cultured relatives $[1-5,26]$. In the acidic environment at Oak Ridge, Asinibacterium spp. OR43 and OR53 could thrive in niches with a higher $\mathrm{pH}$ or in consortia with bacteria that can increase the local $\mathrm{pH}$.

Table 2. Number of genes potentially involved in $\mathrm{pH}$ homeostasis at low $\mathrm{pH}$ in Asinibacterium spp. OR 43 and OR53.

\begin{tabular}{lccc}
\hline Gene Product Name & Gene Symbol & OR43 & OR53 \\
\hline & $a t p G$ & 1 & 1 \\
F-type proton translocating ATPase & $a t p C D$ & 1 & 1 \\
& $a t p B E F H A$ & 1 & 1 \\
High affinity potassium transporter & $k d p A B C D$ & 1 & 1 \\
Low affinity potassium transporter & $k u p$ & 2 & 2 \\
\hline
\end{tabular}

Genes Potentially involved in Uranium Resistance: Phosphatases cleave organoand polyphosphate compounds $[46,47]$ to release inorganic phosphate. The activity of acidic and alkaline phosphatase has been shown to correlate with the formation of extracellular or cell-associated uranyl phosphate precipitates during biomineralization [46-50]. The Asinibacterium spp. OR43 and OR53 genomes contained 34 and 36 phosphatases, respectively (data not shown). However, no acidic or alkaline phosphatases were identified. The absence of acidic or alkaline phosphatase in the genome indicates that Asinibacterium sp. OR53 uses biosorption and not biomineralization as a mechanism of uranium resistance (Figures 4 and 5). During biosorption, uranium can bind to functional groups associated with the cell wall or extracellular structures. The LPS layer is distributed across the cell surface of Gram-negative bacteria and contains phosphate rich regions that support uranium 
binding [25]. Biosorption of uranium has been described for a variety of microorganisms: Sphingomonas spp., Microbacterium spp., Myxococcus xanthus, Streptomyces sporoverrucosus, Pseudomonas spp., and Acidovorax facilis [32,51-56].

Based on the genomic similarities between Asinibacterium sp. OR53 and Asinibacterium sp. OR43, it is likely that Asinibacterium sp. OR43 also uses biosorption as a mechanism to resist high concentrations of uranium too. In summary, the absence of relevant phosphatases in both genomes and the manner in which uranium co-localizes with phosphorus during EDS mapping with Asinibacterium sp. OR53 cells indicates that biosorption of uranium to phosphate groups in the LPS layer is the mechanism of uranium resistance for Asinibacterium spp. OR43 and OR53.

Genes involved in heavy metal metabolism/resistance: We determined genes potentially involved in heavy metal resistance and metabolism by (1) analyzing and comparing the genomes annotated in the JGI IMG/ER database [57] and (2) blasting the complete genome of Asinibacterium sp. OR53 and selected genes of Asinibacterium sp. OR43 against the Antibacterial biocide and metal resistance genes database (BacMet) [58]. In the genomes of Asinibacterium spp. OR43 and OR53, genes potentially involved in the resistance to arsenic, copper, cadmium, cobalt, zinc, mercury, and chromium were identified (Tables 3 and S8).

Table 3. Heavy metal resistance genes in the genomes of Asinibacterium spp. OR43 and OR53.

\begin{tabular}{|c|c|c|c|}
\hline Gene Product Name & Gene Symbol & OR43 & OR53 \\
\hline \multicolumn{4}{|l|}{ Arsenic } \\
\hline Arsenic resistance operon & $\operatorname{ars} B C R$ & 0 & 1 \\
\hline Arsenate reductase (protein-tyrosine phosphatase) & $\operatorname{arsC}$ & 1 & 1 \\
\hline \multicolumn{4}{|l|}{ Copper and silver } \\
\hline Copper exporting P-type ATPase $\left(\mathrm{Cu}^{2+}\right)$ & $\operatorname{cop} A B$ & 1 & 1 \\
\hline Copper exporting P-type ATPase $\left(\mathrm{Cu}^{2+}\right)$ & $\operatorname{cop} A$ & 2 & 2 \\
\hline Copper exporting P-type ATPase $\left(\mathrm{Cu}^{2+}\right)$ & $\operatorname{cop} B$ & 2 & 2 \\
\hline Copper chaperone & $\operatorname{cop} Z$ & 1 & 1 \\
\hline Copper homeostasis protein & cutC & 1 & 1 \\
\hline $\mathrm{Cu}(\mathrm{I}) / \mathrm{Ag}(\mathrm{I})$ efflux system operon & cus $A B$, sil $A B$ & 1 & 3 \\
\hline Copper two component regulatory systems & copRS, cusRS & 4 & 4 \\
\hline \multicolumn{4}{|l|}{ Cobalt, zinc, cadmium } \\
\hline Cobalt-zinc-cadmium resistance operon & $c z c C B A$ & 2 & 1 \\
\hline Heavy metal efflux pump & $c z c A$ & 3 & 3 \\
\hline Membrane fusion protein & $c z c B$ & 2 & 2 \\
\hline Cation diffusion facilitator & $c z c D$ & 2 & 2 \\
\hline $\mathrm{Cd}^{2+} / \mathrm{Zn}^{2+}$ exporting ATPase & $z n t A$ & 1 & 1 \\
\hline \multicolumn{4}{|l|}{ Mercury } \\
\hline Possible transcriptional regulator & merR & 2 & 2 \\
\hline Putative mercury transport protein & merT-P & 2 & 2 \\
\hline Mercury reductase & merA & 1 & 1 \\
\hline Mercury resistance protein & merC & 1 & 1 \\
\hline \multicolumn{4}{|l|}{ Zinc } \\
\hline $\mathrm{Cd}^{2+} / \mathrm{Zn}^{2+}$ exporting ATPase & $z n t A$ & 1 & 1 \\
\hline \multicolumn{4}{|l|}{ Nickel } \\
\hline Nickel transport operon & $n i k A B C E$ & 1 & 1 \\
\hline \multicolumn{4}{|l|}{ Chromium } \\
\hline Chromate transporter & $\operatorname{chr} A$ & 1 & 1 \\
\hline
\end{tabular}

Arsenic: Arsenic resistance is encoded within an operon containing three genes: a transporter $(\operatorname{ars} B)$, reductase $(\operatorname{ars} C)$, and a transcriptional regulator (arsR). All genes within the $\operatorname{ars} R B C$ operon are necessary for conferring arsenic resistance $[59,60]$. It is likely that only Asinibacterium sp. OR53 would be resistant to arsenic since the Asinibacterium sp. 
OR53 genome contained all genes within the operon, while only ars $C$ was identified in the genome of Asinibacterium sp. OR43 (Tables 3 and S8).

Copper: Two different copper resistance mechanisms were detected in the genomes of Asinibacterium spp. OR43 and OR53: (1) copper-transporting ATPases (copA and copB); and (2) proton driven transporters (cusBA) (Tables 3 and S8). copA encodes a copper exporting ATPase, which transports copper from the cytoplasm to the periplasm when copper is present in excess [61,62]. However, the role of copB in copper resistance has not been elucidated for Gram-negative organisms [62]. cusA encodes a RND protein and $c u s B$ encodes a membrane fusion protein of a proton driven transporter. Both genes are present in both genomes, while $\mathrm{cusC}$, the gene for the outer membrane protein, is missing (Tables 3 and S8). Instead, the gene for a putative TolC protein was detected between $c u s A$ and $c u s B$. TolC is an outer membrane protein typically associated with RND transporters $[63,64]$. It is likely the potential tolC gene product encoded between cus $A$ and cusB functions as the outer membrane protein in the absence of cusC [64]. In addition, the gene for the copper binding chaperone copZ and four copies of a copper responsive two-component regulatory system (cusRS) were detected in both strains (Tables 3 and S8). In summary, both strains are very likely resistant to elevated levels of copper.

Cadmium, zinc, and cobalt: The genomes of Asinibacterium spp. OR43 and OR53 contained at least one copy of the full $c z c C B A$ operon and two additional copies of $c z c B A$ (Tables 3 and S8). The genes in the operon encode a cobalt, zinc, and cadmium exporting RND protein $(\mathrm{CzcA})$, a membrane fusion protein $(\mathrm{CzcB})$, and an outer membrane protein $(\mathrm{CzcC})[24,65]$. It is likely that genes located elsewhere in the genome and encoding for nonspecific outer membrane proteins, such as TolC, could allow for heavy metal extrusion in the absence of $\mathrm{CzcC}$ [24]. Both genomes also contained genes for the cation diffusion facilitator $c z c D$ (Tables 3 and S8), which encodes a membrane spanning protein that functions as a metal/proton antiporter for various divalent metals [66]. Previous growth experiments showed that both strains grew at elevated cobalt concentrations and were inhibited by low concentrations of cadmium [21]. These observations are in contrast with the identification of $c z c$ genes in the genomes (Tables 3 and S8). While the efflux pump very likely could contribute to cobalt resistance it may not successfully extrude cadmium.

Nickel: The Asinibacterium spp. OR43 and OR53 genomes did not contain any gene products for the extrusion of nickel (Tables 3 and S8). The genes nikABCDE encode a high affinity $A B C$ nickel transporter that imports nickel into the cell and the gene nikR encodes a repressor that suppresses transcription of nik genes when nickel is in excess [67]. The genes nikA, nikB, nikC, and nikE were found in the genomes of Asinibacterium spp. OR43 and OR53, but not as an operon (Tables 3 and S8). Additionally, the genes encoding NikD, one of the ATP binding proteins, and NikR, the regulatory protein of the nickel transporter were missing from both genomes. In the absence of a nickel exporter and genes necessary for a complete ABC transporter, it would be expected that Asinibacterium spp. OR43 and OR53 are sensitive to the presence of nickel. However, both strains were shown to be resistant to elevated concentrations of nickel [21]. These results suggest that other unidentified transporters may contribute to nickel resistance in Asinibacterium spp. OR43 and OR53.

Mercury: Both Asinibacterium spp. OR43 and OR53 genomes contained two copies of genes encoding a mercury binding protein $($ merP $P)$, mercury transporter $($ mer $T)$, and the transcriptional regulator $(m e r R)$ as well as one copy of the mercury reductase (mer $A$ ) and the mercury resistance gene (merC) (Tables 3 and S8). MerP binds toxic $\mathrm{Hg}^{2+}$ in the periplasm and MerC and MerT transport $\mathrm{Hg}^{2+}$ from the periplasm to the cytoplasm. In the cytoplasm, MerA reduces $\mathrm{Hg}^{2+}$ to a less toxic form $\left(\mathrm{Hg}^{0}\right)$, which diffuses out of the cell $[22,68]$. These results suggest both strains would be resistant to mercury.

Chromium: The gene chrA encodes an efflux pump that was responsible for chromate resistance in P. aeruginosa and Shewanella sp. ANA3 [69,70] that was identified in both genomes (Tables 3 and S8), indicating that Asinibacterium spp. OR43 and OR53 can extrude chromium. 


\section{Material and Methods}

Media: All growth experiments were conducted in mineral salts (MS) medium unless otherwise noted. The MS medium consisted of: $5 \mathrm{mM} \mathrm{NH}_{4} \mathrm{Cl}, 1 \mathrm{mM} \mathrm{NaCl}, 0.25 \mathrm{mM}$ $\mathrm{MgSO}_{4} \bullet 7 \mathrm{H}_{2} \mathrm{O}, 5 \mu \mathrm{M} \mathrm{CaCl}_{2} \bullet 2 \mathrm{H}_{2} \mathrm{O}, 5 \mu \mathrm{M} \mathrm{KH}_{2} \mathrm{PO}_{4}, 10 \mathrm{mM}$ HEPES, and $1 \mathrm{~mL} / \mathrm{L}$ trace elements [71]. The $\mathrm{pH}$ was adjusted with $\mathrm{NaOH}$ to 7.0. After autoclaving, sterile solutions of glucose, tryptone, and yeast extract were added to obtain a final concentration of $0.5 \mathrm{~g} / \mathrm{L}$ in the MS medium. DIFCO Bacto agar $(15 \mathrm{~g} / \mathrm{L})$ was added for agar plates.

To test the growth in the presence of different stress factors nitrate $(0-500 \mathrm{mM})$ as potassium nitrate or uranium $(0-400 \mu \mathrm{M})$ as uranyl acetate was added to the MS medium. Growth at different $\mathrm{pH}$ values was tested in MS medium with $10 \mathrm{mM}$ HEPES as the buffer at $\mathrm{pH} 5-8$ or with $10 \mathrm{mM}$ HOMOPIPES as the buffer at $\mathrm{pH} 3.5-4.5$. Growth under anaerobic conditions was tested in MS medium with nitrate $\left.(200 \mathrm{mM} \mathrm{KNO})_{3}\right)$, uranium $(100 \mu \mathrm{M}$ uranyl acetate), or iron ( $\left.400 \mathrm{mM} \mathrm{FeCl}_{3}\right)$ as terminal electron acceptors.

R2A was used for growing biomass for fatty acid analysis and for the temperature profile [72].

Strains and culture conditions: Asinibacterium spp. OR43 and OR53 (formerly Sediminibacterium spp. OR43 and OR53) were isolated from the highly contaminated subsurface sediment at Oak Ridge, TN [21]. The strains were maintained on MS medium agar plates. If liquid cultures were needed as inoculum for experiments, each strain was inoculated into $5 \mathrm{~mL}$ of liquid MS medium and incubated for 2 days at $27^{\circ} \mathrm{C}$.

Growth in the presence of different stress factors: Pre-cultivated bacterial cultures (15 $\mu \mathrm{L}=1: 10$ dilution or $1.5 \mu \mathrm{L}=1: 100$ dilution) were inoculated into $150 \mu \mathrm{L}$ MS medium in 96-well plates with the different stress factors ( $\mathrm{pH}$, uranium, or nitrate). The plates were incubated at $27^{\circ} \mathrm{C}$ in a plate reader (BIOTEK Synergy HT, Biotek, Winooski, VT, USA) for several days depending on the experiment. The optical density was measured every $10 \mathrm{~min}$ at $600 \mathrm{~nm}\left(\mathrm{OD}_{600}\right)$ after shaking the plate for $10 \mathrm{~s}$. The growth rates were calculated from the slope of the natural log-transformed $\mathrm{OD}_{600}$ data plotted against time.

Carbon utilization: Bacteria were grown to the end of the logarithmic phase in MS medium, centrifuged, washed twice, and re-suspended in MS medium without carbon sources. The $\mathrm{OD}_{600}$ of the culture was adjusted to approximately 0.3 . The cells were inoculated into GN2 MicroPlate ${ }^{\mathrm{TM}}$ (BIOLOG, Hayward, CA, USA). The plates were incubated in the dark at $27^{\circ} \mathrm{C}$ for 5 days and the absorbance was measured once a day in the plate reader (BIOTEK Synergy HT, Biotek, Winooski, VT, USA) at $590 \mathrm{~nm}$. If the the absorbance at $590 \mathrm{~nm}$ was $\geq 0.5$ the strain was considered to be positive for the utilization of each carbon source.

Growth under anaerobic conditions: Pre-cultivated bacteria were inoculated at a 1:10 dilution in each type of medium and observed for 5-9 days for growth. Denitrification was tested in MS medium supplemented with nitrate, iron reduction in MS medium with iron, uranium reduction in MS medium with uranium, and fermentation in MS medium without any additional supplements. All cultures were incubated under anaerobic conditions in an anaerobic chamber ( $5 \%$ hydrogen, $5 \%$ carbon dioxide, and $90 \%$ nitrogen).

Motility: Different modes of motility were tested: swimming, swarming, twitching [73], and gliding [74].

Temperature: The temperature range was determined in a custom-made temperature gradient block that was controlled by a water bath and a heating block. The temperatures were adjusted to values between $4{ }^{\circ} \mathrm{C}$ and $42{ }^{\circ} \mathrm{C}$. The cultures were inoculated into liquid R2A medium in test tubes and incubated in the temperature block. Samples were taken in regular intervals to measure the $\mathrm{OD}_{600}$. The growth rates were calculated as described above.

Biochemical characteristics: Catalase activity was observed as bubble formation after addition of $3 \%(v / v) \mathrm{H}_{2} \mathrm{O}_{2}$. Oxidase activity was determined by the color change of $1 \%$ $\mathrm{N}, \mathrm{N}, \mathrm{N}, \mathrm{N}$-tetramethyl-p-phenylenediamine hydrochloride. $\mathrm{H}_{2} \mathrm{~S}$ production was determined in triple sugar iron (TSI) agar. 
Fatty acid methyl ester analysis was carried out by the identification service of the Deutsche Sammlung von Mikroorganismen und Zellkulturen (DSMZ) (GmbH, Braunschweig, Germany). The bacteria were cultivated on R2A plates for 4 days at $28{ }^{\circ} \mathrm{C}$. Fatty acid methyl esters were analyzed using the Sherlock Microbial Identification System (MIDI) [75-77]. The peaks were identified using the library TSBA40 4.10.

Uranium (VI) assay: Cells were centrifuged in a $1.5 \mathrm{~mL}$ microcentrifuge tube at $28,000 \times g$ for $10 \mathrm{~min}$. The uranium concentration in the supernatant was determined using a colorimetric assay [78].

Transmission Electron Microscopy (TEM): Copper mesh grids with a single layer of $3 \%$ collodion (nitrocellulose) were lightly coated with $20 \mathrm{~nm}$ of carbon. Asinibacterium sp. OR53 was grown to mid-to-late log phase in MS medium with or without $300 \mu \mathrm{M}$ uranium. Cells (1-3 mL) were centrifuged at $9500 \times g$ for $3 \mathrm{~min}$, washed twice with MS medium without carbon sources or phosphate and re-suspended in $0.5-1 \mathrm{~mL}$ of medium. Cells $(10 \mu \mathrm{L})$ were added to the carbon-coated grids and allowed to sit for $2 \mathrm{~min}$. Excess medium and cells were removed with filter paper. Grids were viewed in the JEM-1200 EX II (JEOL, Tokyo, Japan) transmission electron microscope at $100 \mathrm{keV}$.

Scanning Transmission Electron Microscopy (STEM) Elemental Analysis: Copper mesh grids previously prepared for TEM analysis were analyzed under the JEM-2100 (JEOL, Tokyo, Japan) scanning transmission electron microscope (STEM) fitted with a Bruker Quantax energy dispersive X-ray spectroscopy (EDS) system with a XFlash silicon drift detector (SDD) (Bruker, Billerica, MA, USA) at $200 \mathrm{keV}$. Quantax Esprit software (Bruker, Billerica, MA, USA) was used to convert X-ray data into elemental spectrums or maps.

Phylogenetic analysis: DNA was isolated using the Qiagen Blood and Tissue Kit (Qiagen, Valencia, CA, USA) according to the manufacturers' recommendations. The DNA was amplified with the primers $27 \mathrm{~F}$ and 1492R [79]. The PCR products were purified and sequenced using the BigDye Terminator V3.1 cycle sequencing kit (Life Technology Corporation, Carlsbad, CA, USA) on an Applied Biosystems $3730 \times 1$ DNA analyzer (Life Technology Corporation, Carlsbad, CA, USA) at the Center for Bioinformatics and Functional Genomics at Miami University using the 3 internal primers 357F, 518R, and 518F [80]. All sequences were edited with 4Peaks (A. Griekspoor and T. Groothuis, The Netherlands Cancer Institute; http:/ / nucleobytes.com/index.php/4peaks, accessed on 20 December 2021) and aligned using the program ARB version 5.5 [81]. The phylogenetic tree was constructed in MEGA (version 5.2.2) using the maximum likelihood algorithm.

Genome analysis: The draft genomes of Asinibacterium spp. OR43 and OR53 were generated and annotated at the DOE Joint Genome Institute (Walnut Creek, CA, USA) [33]. Further analysis of the genomes was conducted using the JGI-IMG database [57]. Heavy metal resistance genes were identified in the genomes of both strains using the Bac-MetAntibacterial Biocide and Metal Resistance Genes Database (bacmet.biomedicine.gu.se, accessed on 20 December 2021) [58].

\section{Conclusions}

Asinibacterium spp. OR43 and OR53 were isolated from the contaminated subsurface sediment in Oak Ridge, TN. Physiologically, Asinibacterium spp. OR43 and OR53 are similar to other cultured relatives (Tables S1 and S2) and are resistant to elevated concentrations of heavy metals such as uranium (Figure 3), and cobalt and nickel [21]. The resistance of Asinibacterium spp. OR43 and OR53 to uranium, cobalt, and nickel did not necessarily correspond with heavy metal genes identified in the genome. It is likely that uranium resistance in both strains is attributed to biosorption of uranium to the LPS layer. While genes for a cobalt exporter were present in the genome, no genes were identified to explain the resistance of Asinibacterium spp. OR43 and OR53 to nickel, which suggests that these strains might have alternative nickel resistance mechanisms. Additional studies are needed to verify that genes for arsenic, mercury, copper, chromium, and zinc transporters identified in the genome(s) are actually capable of conferring resistance in Asinibacterium spp. OR43 
and/or OR53. Overall, this study showed that Asinibacterium spp. OR43 and OR53 were able to withstand the uranium and nitrate concentrations, but not the low $\mathrm{pH}$ level at the field site in Oak Ridge. Closely related strains are found in significant numbers in the Oak Ridge environment [16] and might have a role in reducing local heavy metal concentrations. To cope with the low $\mathrm{pH}$ levels or other environmental stresses, Asinibacterium spp. OR43 and OR53 might live in consortia with bacteria capable of modifying the local environment so that conditions are favorable for all co-existing microbes.

Supplementary Materials: The following supporting information can be downloaded at: https: / / www.mdpi.com/article/10.3390/bacteria1010004/s1, Table S1: Differential physiological characteristics of strains Asinibacterium spp. OR43 and OR53 in comparison with type strains of closely related species. Table S2: Fatty acid profiles of the strains Asinibacterium spp. OR43 and OR53 in comparison with type strains of closely related species. Table S3: Genome sequencing project information for Asinibacterium spp. OR43 and OR53. Table S4: Genome properties of Asinibacterium spp. OR43 and OR53. Values in parentheses represent the percent (\%) of total genes. Table S5: Number of genes associated with the general COG functional categories in the genomes of Asinibacterium spp. OR43 and OR53. Table S6: Locus information of genes involved in nitrate metabolism in Asinibacterium spp. OR43 and OR53 genomes. Table S7: Locus information of genes involved in $\mathrm{pH}$ homeostasis in the genomes of Asinibacterium spp. OR43 and OR53. Table S8: Potential heavy metal resistance genes in the genome of Asinibacterium spp. OR43 and OR53. The genes potentially involved in heavy metal resistance have been compared to the BacMet-Antibacterial Biocide and Metal Resistance genes database (http:/ / bacmet.biomedicine.gu.se, accessed on 20 December 2021). The identity values (\%) represent the identities of the genes compared to the experimentally verified and predicted database $(x x / x x)$. Figure S1: Uranium concentration in the medium in the presence (with OR53) and absence (without culture) of Asinibacterium sp. OR53 over time (mean $\pm \mathrm{SD} ; \mathrm{n}=3$ ).

Author Contributions: Conceptualization, R.M.B. and A.B.; methodology, R.M.B., R.E.E. and A.B.; formal analysis, R.M.B., R.E.E. and A.B.; writing-original draft preparation, R.M.B. and A.B.; writing-review and editing, R.M.B., R.E.E. and A.B. All authors have read and agreed to the published version of the manuscript.

Funding: This research was funded by start-up funds from Miami University.

Institutional Review Board Statement: Not applicable.

Informed Consent Statement: Not applicable.

Data Availability Statement: The genomes of Asinibacterium sp. OR43 and OR53 have been deposited at Genbank under the accession numbers ATYE00000000 (Asinibacterium sp. OR43) and AZXP00000000 (Asinibacterium sp. OR53). The raw reads have been deposited in the SRA under SRP078705 (Asinibacterium sp. OR53) and SRP078706 (Asinibacterium sp. OR43). Both genomes can also be accessed via the Integrated Microbial Genomes and Microbiomes database of the US Department of Energy-Joint Genome Institute (JGI-IMG) with the IMG genome ID 2509887033 (Asinibacterium sp. OR43) and 2516143025 (Asinibacterium sp. OR53).

Conflicts of Interest: The authors declare no conflict of interest.

\section{References}

1. Kämpfer, P.; Lodders, N.; Falsen, E. Hydrotalea flava Gen. Nov., Sp. Nov., a New Member of the Phylum Bacteroidetes and Allocation of the Genera Chitinophaga, Sediminibacterium, Lacibacter, Flavihumibacter, Flavisolibacter, Niabella, Niastella, Segetibacter, Parasegetibacter, Terrimonas, Ferruginibacter, Filimonas and Hydrotalea to the Family Chitinophagaceae Fam. Nov. Int. J. Syst. Evol. Microbiol. 2011, 61, 518-523. [CrossRef]

2. $\quad$ Lee, D.-G.; Park, J.-M.; Kang, H.; Hong, S.-Y.; Lee, K.R.; Chang, H.-B.; Trujillo, M.E. Asinibacterium lactis Gen. Nov., Sp. Nov., a Member of the Family Chitinophagaceae, Isolated from Donkey (Equus asinus) Milk. Int. J. Syst. Evol. Microbiol. 2013, 63, 3180-3185. [CrossRef] [PubMed]

3. Albuquerque, L.; Rainey, F.A.; Nobre, M.F.; Costa, M.S.D. Hydrotalea sandarakina Sp. Nov., Isolated from a Hot Spring Runoff, and Emended Descriptions of the Genus Hydrotalea and the Species Hydrotalea flava. Int. J. Syst. Evol. Microbiol. 2012, 62, 1603-1608. [CrossRef] 
4. Kim, Y.-J.; Nguyen, N.-L.; Weon, H.-Y.; Yang, D.-C. Sediminibacterium ginsengisoli Sp. Nov., Isolated from Soil of a Ginseng Field, and Emended Descriptions of the Genus Sediminibacterium and of Sediminibacterium salmoneum. Int. J. Syst. Evol. Microbiol. 2013, 63, 905-912. [CrossRef]

5. Kang, H.; Kim, H.; Lee, B.-I.; Joung, Y.; Joh, K. Sediminibacterium goheungense Sp. Nov., Isolated from a Freshwater Reservoir. Int. J. Syst. Evol. Microbiol. 2014, 64, 1328-1333. [CrossRef] [PubMed]

6. Qu, J.-H.; Yuan, H.-L. Sediminibacterium salmoneum Gen. Nov., Sp. Nov., a Member of the Phylum Bacteroidetes Isolated from Sediment of a Eutrophic Reservoir. Int. J. Syst. Evol. Microbiol. 2008, 58, 2191-2194. [CrossRef] [PubMed]

7. Pisciotta, J.M.; Zou, Y.; Baskakov, I.V. Light-Dependent Electrogenic Activity of Cyanobacteria. PLoS ONE 2010, 5, e10821. [CrossRef] [PubMed]

8. Dillon, J.G.; Carlin, M.; Gutierrez, A.; Nguyen, V.; McLain, N. Patterns of Microbial Diversity along a Salinity Gradient in the Guerrero Negro Solar Saltern, Baja CA Sur, Mexico. Front. Microbiol. 2013, 4, 399. [CrossRef]

9. Bagatini, I.; Eiler, A.; Bertilsson, S.; Klaveness, D.; Tessarolli, L.P.; Vieira, A.A.H. Host-Specificity and Dynamics in Bacterial Communities Associated with Bloom-Forming Freshwater Phytoplankton. PLoS ONE 2014, 9, e85950. [CrossRef]

10. Besemer, K.; Peter, H.; Logue, J.B.; Langenheder, S.; Lindström, E.; Tranvik, L.J.; Battin, T.J. Unraveling Assembly of Stream Biofilm Communities. ISME J. 2012, 6, 1459-1468. [CrossRef]

11. Youngblut, N.D.; Shade, A.; Read, J.; McMahon, K.D.; Whitaker, R.J. Lineage-Specific Responses of Microbial Communities to Environmental Change. Appl. Environ. Microbiol. 2012, 79, 39-47. [CrossRef] [PubMed]

12. Cai, H.; Jiang, H.; Krumholz, L.R.; Yang, Z. Bacterial Community Composition of Size-Fractioned Aggregates within the Phycosphere of Cyanobacterial Blooms in a Eutrophic Freshwater Lake. PLoS ONE 2014, 9, e102879. [CrossRef] [PubMed]

13. Medihala, P.; Lawrence, J.; Swerhone, G.; Korber, D. Transient Response of Microbial Communities in a Water Well Field to Application of an Impressed Current. Water Res. 2013, 47, 672-682. [CrossRef] [PubMed]

14. Arias-Cordero, E.; Ping, L.; Reichwald, K.; Delb, H.; Platzer, M.; Boland, W. Comparative Evaluation of the Gut Microbiota Associated with the Below- and Above-Ground Life Stages (Larvae and Beetles) of the Forest Cockchafer, Melolontha hippocastani. PLoS ONE 2012, 7, e51557. [CrossRef] [PubMed]

15. Reti, K.L.; Thomas, M.C.; Yanke, L.J.; Selinger, L.B.; Inglis, G.D. Effect of Antimicrobial Growth Promoter Administration on the Intestinal Microbiota of Beef Cattle. Gut Pathog. 2013, 5, 8. [CrossRef] [PubMed]

16. Abulencia, C.B.; Wyborski, D.L.; Garcia, J.A.; Podar, M.; Chen, W.; Chang, S.H.; Chang, H.W.; Watson, D.; Brodie, E.L.; Hazen, T.; et al. Environmental Whole-Genome Amplification to Access Microbial Populations in Contaminated Sediments. Appl. Environ. Microbiol. 2006, 72, 3291-3301. [CrossRef] [PubMed]

17. Singleton, D.R.; Richardson, S.D.; Aitken, M.D. Pyrosequence Analysis of Bacterial Communities in Aerobic Bioreactors Treating Polycyclic Aromatic Hydrocarbon-Contaminated Soil. Biodegradation 2011, 22, 1061-1073. [CrossRef]

18. Al-Awadhi, H.; Dashti, N.; Khanafer, M.; Al-Mailem, D.; Ali, N.; Radwan, S. Bias Problems in Culture-Independent Analysis of Environmental Bacterial Communities: A Representative Study on Hydrocarbonoclastic Bacteria. SpringerPlus 2013, 2, 369. [CrossRef]

19. Laplante, K.; Sébastien, B.; Derome, N. Parallel Changes of Taxonomic Interaction Networks in Lacustrine Bacterial Communities Induced by a Polymetallic Perturbation. Evol. Appl. 2013, 6, 643-659. [CrossRef]

20. Callbeck, C.; Agrawal, A.; Voordouw, G.; Ishii, Y.; Matsuura, Y.; Kakizawa, S.; Nikoh, N.; Fukatsu, T. Acetate Production from Oil under Sulfate-Reducing Conditions in Bioreactors Injected with Sulfate and Nitrate. Appl. Environ. Microbiol. 2013, 79, 5059-5068. [CrossRef]

21. Bollmann, A.; Palumbo, A.V.; Lewis, K.; Epstein, S.S. Isolation and Physiology of Bacteria from Contaminated Subsurface Sediments. Appl. Environ. Microbiol. 2010, 76, 7413-7419. [CrossRef]

22. Nies, D.H. Microbial Heavy-Metal Resistance. Appl. Microbiol. Biotechnol. 1999, 51, 730-750. [CrossRef] [PubMed]

23. Bruins, M.R.; Kapil, S.; Oehme, F.W. Microbial Resistance to Metals in the Environment. Ecotoxicol. Environ. Saf. 2000, 45, 198-207. [CrossRef]

24. Nies, D.H. Efflux-Mediated Heavy Metal Resistance in Prokaryotes. FEMS Microbiol. Rev. 2003, 27, 313-339. [CrossRef]

25. Newsome, L.; Morris, K.; Lloyd, J. The Biogeochemistry and Bioremediation of Uranium and other Priority Radionuclides. Chem. Geol. 2013, 363, 164-184. [CrossRef]

26. Albert, R.A.; Zitomer, D.; Dollhopf, M.; Schauer-Gimenez, A.E.; Struble, C.; King, M.; Son, S.; Langer, S.; Busse, H.-J. Proposal of Vibrionimonas magnilacihabitans Gen. Nov., Sp. Nov., a Curved Gram-Stain-Negative Bacterium Isolated from Lake Water. Int. J. Syst. Evol. Microbiol. 2014, 64, 613-620. [CrossRef] [PubMed]

27. Ayarza, J.M.; Figuerola, E.L.M.; Erijman, L. Draft Genome Sequences of Type Strain Sediminibacterium salmoneum NJ-44 and Sediminibacterium sp. Strain C3, a Novel Strain Isolated from Activated Sludge. Genome Announc. 2014, 2, e01073-13. [CrossRef] [PubMed]

28. Dhal, P.K.; Islam, E.; Kazy, S.K.; Sar, P. Culture-Independent Molecular Analysis of Bacterial Diversity in Uranium-Ore/-Mine Waste-Contaminated and Non-Contaminated Sites from Uranium Mines. 3 Biotech 2011, 1, 261-272. [CrossRef]

29. Limbri, H.; Gunawan, C.; Thomas, T.; Smith, A.; Scott, J.; Rosche, B. Coal-Packed Methane Biofilter for Mitigation of Green House Gas Emissions from Coal Mine Ventilation Air. PLoS ONE 2014, 9, e94641. [CrossRef]

30. Eberdugo-Clavijo, C.; Gieg, L.M. Conversion of Crude Oil to Methane by a Microbial Consortium Enriched from Oil Reservoir Production Waters. Front. Microbiol. 2014, 5, 197. [CrossRef] 
31. Brzoska, R.M.; Bollmann, A. The long-term effect of uranium and $\mathrm{pH}$ on the community composition of an artificial consortium. FEMS Microbiol. Ecol. 2015, 92, fiv158. [CrossRef] [PubMed]

32. Barkleit, A.; Moll, H.; Bernhard, G. Interaction of Uranium(vi) with Lipopolysaccharide. Dalton Trans. 2008, 21, 2879-2886. [CrossRef] [PubMed]

33. Brzoska, R.M.; Huntemann, M.; Clum, A.; Chen, A.; Kyrpides, N.; Palaniappan, K.; Ivanova, N.; Mikhailova, N.; Ovchinnikova, G.; Varghese, N.; et al. Complete Genome Sequence for Asinibacterium sp. Strain OR53 and Draft Genome Sequence for Asinibacterium sp. Strain OR43, Two Bacteria Tolerant to Uranium. Microbiol. Resour. Announc. 2019, 8, e01701-18. [CrossRef] [PubMed]

34. Goris, J.; Konstantinidis, K.T.; Klappenbach, J.A.; Coenye, T.; Vandamme, P.; Tiedje, J.M. DNA-DNA Hybridization Values and their Relationship to Whole-Genome Sequence Similarities. Int. J. Syst. Evol. Microbiol. 2007, 57, 81-91. [CrossRef]

35. Varghese, N.J.; Mukherjee, S.; Ivanova, N.; Konstantinidis, K.T.; Mavrommatis, K.; Kyrpides, N.C.; Pati, A. Microbial Species Delineation Using Whole Genome Sequences. Nucleic Acids Res. 2015, 43, 6761-6771. [CrossRef]

36. Zumft, W. Cell Biology and Molecular Basis of Denitrification. Microbiol. Mol. Biol. Rev. 1997, 61, $533-616$.

37. Hino, T.; Nagano, S.; Sugimoto, H.; Tosha, T.; Shiro, Y. Molecular Structure and Function of Bacterial Nitric Oxide Reductase. Biochim. Biophys. Acta 2011, 1817, 680-687. [CrossRef]

38. Tavares, P.; Pereira, A.S.; Moura, J.; Moura, I. Metalloenzymes of the Denitrification Pathway. J. Inorg. Biochem. 2006, 100, 2087-2100. [CrossRef]

39. Pauleta, S.R.; Dell'Acqua, S.; Moura, I. Nitrous Oxide Reductase. Co-ord. Chem. Rev. 2012, 257, 332-349. [CrossRef]

40. Smith, J.L.; Liu, Y.; Paoli, G.C. How Does Listeria monocytogenes combat Acid Conditions? Can. J. Microbiol. 2013, 59, 141-152. [CrossRef]

41. Phan-Thanh, L.; Mahouin, F. A Proteomic Approach to Study the Acid Response in Listeria monocytogenes. ELECTROPHORESIS Int. J. 1999, 20, 2214-2224. [CrossRef]

42. Olson, E.R. Influence of pH on Bacterial Gene Expression. Mol. Microbiol. 1993, 8, 5-14. [CrossRef]

43. Kobayashi, H.; Saito, H.; Kakegawa, T. Bacterial Strategies to Inhabit Acidic Environments. J. Gen. Appl. Microbiol. 2000, 46, 235-243. [CrossRef]

44. Trchounian, A.; Kobayashi, H. Kup Is the Major K+uptake System in Escherichia coli upon Hyper-Osmotic Stress at a Low pH. FEBS Lett. 1999, 447, 144-148. [CrossRef]

45. Foster, J.W. Escherichia coli Acid Resistance: Tales of an Amateur Acidophile. Nat. Rev. Genet. 2004, 2, 898-907. [CrossRef]

46. Macaskie, L.E.; Bonthrone, K.M.; Yong, P.; Goddard, D.T. Enzymically Mediated Bioprecipitation of Uranium by a Citrobacter sp.: A Concerted Role for Exocellular Lipopolysaccharide and Associated Phosphatase in Biomineral Formation. Microbiology 2000, 146, 1855-1867. [CrossRef] [PubMed]

47. Renninger, N.; Knopp, R.; Nitsche, H.; Clark, D.S.; Keasling, J.D. Uranyl Precipitation by Pseudomonas aeruginosa via Controlled Polyphosphate Metabolism. Appl. Environ. Microbiol. 2004, 70, 7404-7412. [CrossRef]

48. Martinez, R.; Beazley, M.; Taillefert, M.; Arakaki, A.K.; Skolnick, J.; Sobecky, P.A. Aerobic Uranium (VI) Bioprecipitation by Metal-Resistant Bacteria Isolated from Radionuclide- and Metal-Contaminated Subsurface Soils. Environ. Microbiol. 2007, 9, 3122-3133. [CrossRef]

49. Nilgiriwala, K.; Alahari, A.; Rao, A.S.; Apte, S.K. Cloning and Overexpression of Alkaline Phosphatase PhoK from Sphingomonas sp. Strain BSAR-1 for Bioprecipitation of Uranium from Alkaline Solutions. Appl. Environ. Microbiol. 2008, 74, 5516-5523. [CrossRef] [PubMed]

50. Kulkarni, S.; Misra, C.S.; Gupta, A.; Ballal, A.; Apte, S.K. Interaction of Uranium with Bacterial Cell Surfaces: Inferences from Phosphatase-Mediated Uranium Precipitation. Appl. Environ. Microbiol. 2016, 82, 4965-4974. [CrossRef] [PubMed]

51. Choudhary, S.; Sar, P. Uranium Biomineralization by a Metal Resistant Pseudomonas aeruginosa Strain Isolated from Contaminated Mine Waste. J. Hazard. Mater. 2011, 186, 336-343. [CrossRef]

52. Nedelkova, M.; Merroun, M.L.; Rossberg, A.; Hennig, C.; Selenska-Pobell, S. Microbacterium Isolates from the Vicinity of a Radioactive Waste Depository and their Interactions with Uranium. FEMS Microbiol. Ecol. 2007, 59, 694-705. [CrossRef]

53. Merroun, M.; Nedelkova, M.; Rossberg, A.; Hennig, C.; Selenska-Pobell, S. Interaction Mechanisms of Bacterial Strains Isolated from Extreme Habitats with Uranium. Radiochim. Acta 2006, 94, 723-729. [CrossRef]

54. Jroundi, F.; Merroun, M.L.; Arias, J.M.; Rossberg, A.; Selenska-Pobell, S.; Gonzalez-Muñoz, M.T. Spectroscopic and Microscopic Characterization of Uranium Biomineralization in Myxococcus Xanthus. Geomicrobiol. J. 2007, 24, 441-449. [CrossRef]

55. Li, X.; Ding, C.; Liao, J.; Du, L.; Sun, Q.; Yang, J.; Yang, Y.; Zhang, D.; Tang, J.; Liu, N. Bioaccumulation Characterization of Uranium by a Novel Streptomyces sporoverrucosus dwc-3. J. Environ. Sci. 2016, 41, 162-171. [CrossRef]

56. Gerber, U.; Zirnstein, I.; Krawczyk-Bärsch, E.; Lünsdorf, H.; Arnold, T.; Merroun, M. Combined Use of Flow Cytometry and Microscopy to Study the Interactions between the Gram-Negative Betaproteobacterium Acidovorax facilis and Uranium (VI). J. Hazard. Mater. 2016, 317, 127-134. [CrossRef] [PubMed]

57. Chen, I.-M.A.; Chu, K.; Palaniappan, K.; Pillay, M.; Ratner, A.; Huang, J.; Huntemann, M.; Varghese, N.; White, J.R.; Seshadri, R.; et al. IMG/M v.5.0: An Integrated Data Management and Comparative Analysis System for Microbial Genomes and Microbiomes. Nucleic Acids Res. 2018, 47, D666-D677. [CrossRef] [PubMed]

58. Pal, C.; Bengtsson-Palme, J.; Rensing, C.; Kristiansson, E.; Larsson, D.G.J. BacMet: Antibacterial Biocide and Metal Resistance Genes Database. Nucleic Acids Res. 2013, 42, D737-D743. [CrossRef] [PubMed] 
59. Silver, S.; Phung, L.T. Bacterial Heavy Metal Resistance: New Surprises. Annu. Rev. Microbiol. 1996, 50, 753-789. [CrossRef]

60. Hobman, J.; Crossman, L.C. Bacterial Antimicrobial Metal Ion Resistance. J. Med Microbiol. 2015, 64, 471-497. [CrossRef]

61. Ladomersky, E.; Petris, M.J. Copper Tolerance and Virulence in Bacteria. Metallomics 2015, 7, 957-964. [CrossRef] [PubMed]

62. Bondarczuk, K.; Piotrowska-Seget, Z. Molecular Basis of Active Copper Resistance Mechanisms in Gram-Negative Bacteria. Cell Biol. Toxicol. 2013, 29, 397-405. [CrossRef] [PubMed]

63. Rensing, C.; Grass, G. Escherichia coli Mechanisms of Copper Homeostasis in a Changing Environment. FEMS Microbiol. Rev. 2003, 27, 197-213. [CrossRef]

64. Alvarez-Ortega, C.; Olivares, J.; Martínez, J.L. RND Multidrug Efflux Pumps: What Are they Good for? Front. Microbiol. 2013 , 4, 7. [CrossRef]

65. Goldberg, M.; Pribyl, T.; Juhnke, S.; Nies, D.H. Energetics and Topology of CzcA, a Cation/Proton Antiporter of the ResistanceNodulation-Cell Division Protein Family. J. Biol. Chem. 1999, 274, 26065-26070. [CrossRef]

66. Kolaj-Robin, O.; Russell, D.; Hayes, K.; Pembroke, T.; Soulimane, T. Cation Diffusion Facilitator Family: Structure and Function. FEBS Lett. 2015, 589, 1283-1295. [CrossRef]

67. Eitinger, T.; Mandrand-Berthelot, M.-A. Nickel Transport Systems in Microorganisms. Arch. Microbiol. 2000, 173, 1-9. [CrossRef]

68. Barkay, T.; Miller, S.M.; Summers, A.O. Bacterial Mercury Resistance from Atoms to Ecosystems. FEMS Microbiol. Rev. 2003, 27, 355-384. [CrossRef]

69. Alvarez, A.H.; Moreno-Sánchez, R.; Cervantes, C. Chromate Efflux by Means of the ChrA Chromate Resistance Protein from Pseudomonas aeruginosa. J. Bacteriol. 1999, 181, 7398-7400. [CrossRef]

70. Aguilar-Barajas, E.; Paluscio, E.; Cervantes, C.; Rensing, C. Expression of Chromate Resistance Genes from Shewanella sp. Strain ANA-3 in Escherichia Coli. FEMS Microbiol. Lett. 2008, 285, 97-100. [CrossRef]

71. Bollmann, A.; French, E.; Laanbroek, H.J. Isolation, Cultivation, and Characterization of Ammonia-Oxidizing Bacteria and Archaea Adapted to Low Ammonium Concentrations. Methods Enzymol. 2011, 486, 55-88. [CrossRef] [PubMed]

72. Reasoner, D.J.; Geldreich, E.E. A New Medium for the Enumeration and Subculture of Bacteria from Potable Water. Appl. Environ. Microbiol. 1985, 49, 1-7. [CrossRef] [PubMed]

73. Rashid, M.H.; Kornberg, A. Inorganic Polyphosphate Is Needed for Swimming, Swarming, and Twitching Motilities of Pseudomonas aeruginosa. Proc. Natl. Acad. Sci. USA 2000, 97, 4885-4890. [CrossRef]

74. Hatchel, J.M.; Balish, R.S.; Duley, M.L.; Balish, M.F. Ultrastructure and Gliding Motility of Mycoplasma amphoriforme, a Possible Human respiratory Pathogen. Microbiology 2006, 152, 2181-2189. [CrossRef] [PubMed]

75. Miller, L.T. Single Derivatization Method for Routine Analysis of Bacterial Whole-Cell Fatty Acid Methyl Esters, Including Hydroxy Acids. J. Clin. Microbiol. 1982, 16, 584-586. [CrossRef] [PubMed]

76. Kuykendall, L.D.; Roy, M.A.; O’Neill, J.J.; Devine, T.E. Fatty Acids, Antibiotic Resistance, and Deoxyribonucleic Acid Homology Groups of Bradyrhizobium japonicum. Int. J. Syst. Bacteriol. 1988, 38, 358-361. [CrossRef]

77. Kämpfer, P.; Kroppenstedt, R.M. Numerical Analysis of Fatty Acid Patterns of Coryneform Bacteria and Related Taxa. Can. J. Microbiol. 1996, 42, 989-1005. [CrossRef]

78. Teixeira, L.S.G.; Costa, A.C.S.; Ferreira, S.L.C.; Freitas, M.D.L.; Carvalho, M.S.D. Spectrophotometric Determination of Uranium Using 2-(2-Thiazolylazo)-p-Cresol (TAC) in the Presence of Surfactants. J. Braz. Chem. Soc. 1999, 10, 519-522. [CrossRef]

79. Weisburg, W.G.; Barns, S.M.; Pelletier, D.A.; Lane, D.J. 16S Ribosomal DNA Amplification for Phylogenetic Study. J. Bacteriol. 1991, 173, 697-703. [CrossRef]

80. Muyzer, G.; de Waal, E.C.; Uitterlinden, A.G. Profiling of Complex Microbial Populations by Denaturing Gradient Gel Electrophoresis Analysis of Polymerase Chain Reaction-Amplified Genes Coding for 16S rRNA. Appl. Environ. Microbiol. 1993, 59, 695-700. [CrossRef]

81. Ludwig, W.; Strunk, O.; Westram, R.; Richter, L.; Meier, H.; Yadhukumar; Buchner, A.; Lai, T.; Steppi, S.; Jobb, G.; et al. ARB: A Software Environment for Sequence Data. Nucleic Acids Res. 2004, 32, 1363-1371. [CrossRef] [PubMed] 